\title{
Oil and alginate content in Hydroclathrus clathratus of the st. martin's Island, Bangladesh
}

\section{Oil and alginate content in Hydroclathrus}

Seaweeds are sedentary macrophytes growing vastly on rocks and other plants in the inter-tidal and sub-tidal zone of the marine environment. In Bangladesh commercially important species of seaweeds is reported to be very low. ${ }^{1}$ The rocky shore of the St. Martin's Island is a wealthy source of various naturally growing seaweeds. ${ }^{2}$ Hydroclathrus clathratus is one of the available seaweeds found in the St. Martin's Island but like other seaweed species it is still not exploited commercially in Bangladesh. This plant is usually 10-20 $\mathrm{cm}$ in diameter, very irregularly globose and much convoluted, with variously sized perforations over the whole thallus having a wall of 3-6 layers of cells. ${ }^{3}$ The species is reported to be used partially as food and fertilizer in India ${ }^{4}$ and as a commercial food species in Philippines. Wang et al. ${ }^{5}$ isolated antiviral polysaccharides from $H$. clathratus in Hong Kong. Till now there is no record on oil and alginate content in H. clathratus is available. This study was undertaken to determine the oil and alginate content in $H$. clathratus which is flourish naturally in the St. Martin's Island during dry season. Seaweed samples (Figure 1) were collected using sharp knife from the intertidal shore area, at two locations Latitude $20^{\circ} 37^{\prime} \mathrm{N}$ and Longitude $92^{\circ} 19^{\prime} \mathrm{E}$ and Latitude $20^{\circ} 36^{\prime} \mathrm{N}$ and Longitude $92^{\circ} 19^{\prime} \mathrm{E}$ of the St. Martin's Island during February to April, 2006.

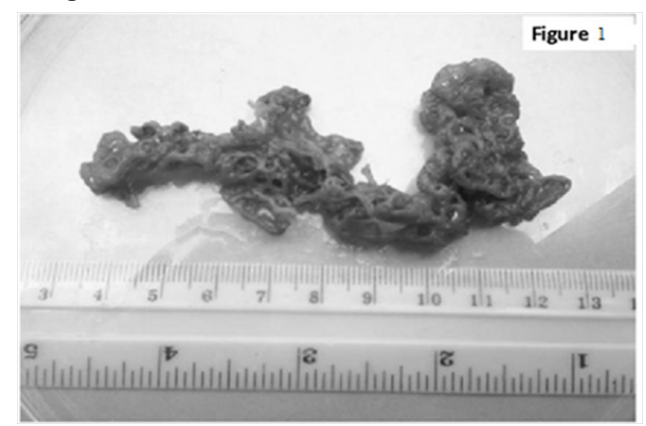

Figure I Hydroclathrus clathratus found in the St. Martin's Island, Bangladesh. Table I Oil and sodium alginate content in H. clathratus of the St. Martins Island
Volume 3 Issue 5 - 2018

\author{
Rashedul Alam Chowdhury SM, Mohammad \\ Zafar \\ Institute of Marine Sciences and Fisheries, University of \\ Chittagong, Bangladesh
}

Correspondence: Rashedul Alam Chowdhury M, Institute
of Marine Sciences and Fisheries, University of Chittagong,
Chittagong- 433।, Bangladesh, Tel 880। 8I8। 04835, Fax 880 I726 310, Email rac.imsf@gmail.com

Received: July 31, 2017 | Published: September 19, 2018

After removing the unwanted matter, samples were washed thoroughly with sea water and half of the collected fresh samples were prepared for analysis of Oil and alginate content. The rest of the samples were kept on a tray in open field under the sun for drying. In the laboratory Oil content was determined by Soxhlet extraction ${ }^{6}$ using petroleum ether $\left(40\right.$ to $\left.60^{\circ} \mathrm{C}\right)$ for $5 \mathrm{~h}$, followed by solvent removal under vacuum at $40^{\circ} \mathrm{C}$. The percentage of alginate, as sodium alginate, was determined following the methods of McHugh. ${ }^{7}$ Correlation analysis was done to assess the relationship between oil and sodium alginate content in H. clathratus both on fresh and sundry weight basis respectively. Oil content of $H$. clathratus was found $2.215 \pm 0.155 \mathrm{~g} / \mathrm{kg}$ on wet weight basis and $2.97 \pm 0.21 \mathrm{~g} / \mathrm{kg}$ on dry wt. basis (Table 1). No published report was found on oil content of $H$. clathratus. Senthil ${ }^{8}$ reported the oil contents $2.14 \mathrm{~g} / \mathrm{kg}$ in Eucheuma sp. The percentage of alginate (as Sodium alginate) was found $36.04 \pm 1.81 \%$ on wet wt. basis and $42.86 \pm 1.95 \%$ on dry wt. basis (Table 1) respectively. Sodium alginate content was found higher during February, 2006 when the species was in its full bloom.

\begin{tabular}{lllll}
\hline & \multicolumn{2}{l}{ Oil content $(\mathbf{g} / \mathbf{k g})$} & \multicolumn{2}{l}{ Sodium alginate content $(\%)$} \\
\cline { 2 - 5 } & Fresh basis & Sun dry basis & Fresh basis & Sun dry basis \\
\hline Max. & 2.31 & 3.12 & 37.88 & 45.96 \\
Min. & 2.155 & 2.83 & 34.41 & 40.8 \\
Mean & 2.215 & 2.97 & 36.04 & 42.86 \\
\pm SD & 0.155 & 0.21 & 1.81 & 1.95 \\
\hline
\end{tabular}

Correlation coefficient showed (Figure 2) that there is a significant positive correlation $(r=0.843558, \mathrm{p}<0.05)$ between Sodium alginate content in sun dried seaweed sample with Oil content on fresh wt. basis in $H$. clathratus. No significant variations were recorded in oil and alginate content in $H$. clathratus during the study period on
February to April, 2006. High percentage of Sodium alginate and significant amount of oil content were found in $H$. clathratus of St. Martin's Island. Therefore this brown alga may be used for extraction of oil and also as an ingredient of valuable pharmaceutical products. 


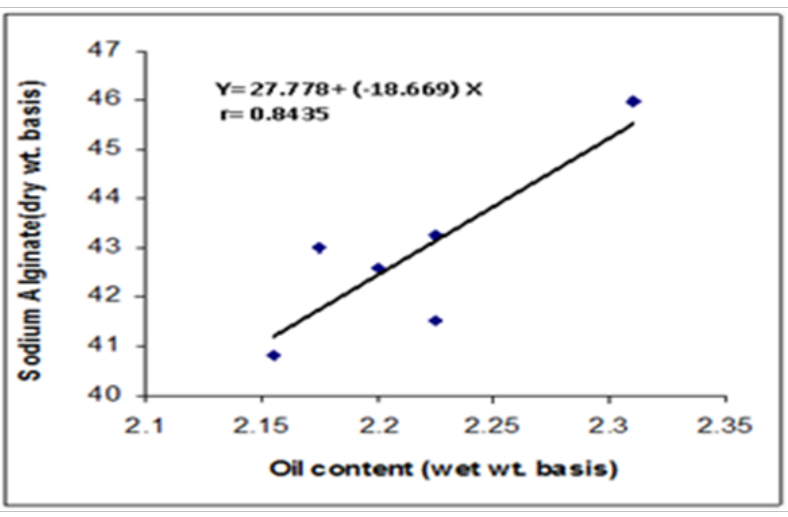

Figure 2 Correlation between Sodium alginate content and Oil content in H. clathratus.

\section{Acknowledgements}

This work was part of a research project on seaweed culture funded by the University Grand Commission (UGC), Bangladesh. We sincerely acknowledge the financial support of the UGC.

\section{Conflict on interest}

The authors declare there is conflict on interest.

\section{References}

1. Islam AKMN. Preliminary Ecological Report on the Marine Algal Flora of the St. Martin's Island. East Pakistan. J Asiatic Soc Pakistan. 1970;15(3):283.

2. Zafar M. Seaweed culture in Bangladesh holds promise. INFOFISH Int 2005:8-10.

3. Johnson KA, Dromgoole FI. Occurrence of Hydroclathrus clathratus in northern New Zealand waters. N.Z. Jour of Marand Freshwater Res. 1977;11(2):269-272.

4. Dhargalkar VK, Pereira N. Seaweed: promising plant of the millennium. Science and Culture. National Institute of Oceanography, Goa, India. 2005:1-7.

5. Wang H, Ooi EV. Antiviral polysaccharides isolated from Hong Kong brown seaweed Hydroclathrus clathratus. Sci China C Life Sci. 2007;50(5):611-618.

6. AOCS. Official Methods and Recommended Practices of the American Oil Chemists Society. Champaign, IL: AOCS; 1989.

7. McHugh DJ. A Guide to the seaweed industry. FAO Fisheries Technical Paper. No. 441 Rome, FAO. 2003:1-118.

8. Senthil A. Effect of using seaseed (Euchauma) powder on the qulity of fish cutlet. Int Jour of Food Sci and Nut. 2005;56(5):350-357. 
